\title{
Calcification responses of symbiotic and aposymbiotic corals to near-future levels of ocean acidification
}

\author{
S. Ohki ${ }^{1}$, T. Irie ${ }^{2}$, M. Inoue ${ }^{2}$, K. Shinmen ${ }^{2}$, H. Kawahata ${ }^{2}$, T. Nakamura ${ }^{3}$, A. Kato ${ }^{1}$, Y. Nojiri ${ }^{4}$, A. Suzuki ${ }^{5}$, K. Sakai ${ }^{1}$, \\ and R. van Woesik ${ }^{6}$ \\ ${ }^{1}$ Sesoko Station, Tropical Biosphere Research Center, University of the Ryukyus, Motobu, Okinawa \\ 905-0227, Japan \\ ${ }^{2}$ Atmosphere and Ocean Research Institute, The University of Tokyo, Kashiwa, Chiba 277-8564, Japan \\ ${ }^{3}$ Faculty of Science, University of the Ryukyus, Nishihara, Okinawa 903-0213, Japan \\ ${ }^{4}$ Center for Global Environmental Research, National Institute for Environmental Studies, Tsukuba, \\ Ibaraki 305-8506, Japan \\ ${ }^{5}$ Geological Survey of Japan, National Institute of Advanced Industrial Science and Technology (AIST), \\ Tsukuba, Ibaraki 305-8567, Japan \\ ${ }^{6}$ Department of Biological Sciences, Florida Institute of Technology, 150 West University Drive, Melbourne, \\ Florida 32901, USA
}

Correspondence to: A. Suzuki (a.suzuki@aist.go.jp)

Received: 5 April 2013 - Published in Biogeosciences Discuss.: 19 April 2013

Revised: 24 August 2013 - Accepted: 29 August 2013 - Published: 1 November 2013

\begin{abstract}
Increasing the acidity of ocean waters will directly threaten calcifying marine organisms such as reef-building scleractinian corals, and the myriad of species that rely on corals for protection and sustenance. Ocean $\mathrm{pH}$ has already decreased by around $0.1 \mathrm{pH}$ units since the beginning of the industrial revolution, and is expected to decrease by another $0.2-0.4 \mathrm{pH}$ units by 2100 . This study mimicked the preindustrial, present, and near-future levels of $p \mathrm{CO}_{2}$ using a precise control system $\left( \pm 5 \% p \mathrm{CO}_{2}\right)$, to assess the impact of ocean acidification on the calcification of recently settled primary polyps of Acropora digitifera, both with and without symbionts, and adult fragments with symbionts. The increase in $p \mathrm{CO}_{2}$ of $\sim 100 \mu \mathrm{atm}$ between the pre-industrial period and the present had more effect on the calcification rate of adult $A$. digitifera than the anticipated future increases of several hundreds of micro-atmospheres of $p \mathrm{CO}_{2}$. The primary polyps with symbionts showed higher calcification rates than primary polyps without symbionts, suggesting that: (i) primary polyps housing symbionts are more tolerant to nearfuture ocean acidification than organisms without symbionts, and (ii) corals acquiring symbionts from the environment (i.e., broadcasting species) will be more vulnerable to ocean acidification than corals that maternally acquire symbionts.
\end{abstract}

\section{Introduction}

As humans continue to burn fossil fuels at an unprecedented rate, the concentration of $\mathrm{CO}_{2}$ in the atmosphere is presently higher than it has been for the last $420000 \mathrm{yr}$ (Hoegh-Guldberg et al., 2007; IPCC, 2007). The oceans uptake a large proportion of that $\mathrm{CO}_{2}$, forcing them toward more acidic conditions (i.e., with high $p \mathrm{CO}_{2}$ ), threatening the very foundation of calcifying marine organisms and coral reefs (Kleypas et al., 2006; Orr et al., 2005; Raven et al., 2005). Indeed, coral reefs support a wealth of calcifying organisms, of which scleractinian corals have been the most essential reef builder since the Triassic (Stanley and Fautin, 2001).

Since the pre-industrial period, we have witnessed a steady increase in $p \mathrm{CO}_{2}$ concentrations from $<300 \mu$ atm to present concentrations of $400 \mu \mathrm{atm} . p \mathrm{CO}_{2}$ is predicted to reach 200 to $700 \mu$ atm above present levels by 2100 . (IPCC, 2007). Such an increase in $p \mathrm{CO}_{2}$ reduces both the $\mathrm{pH}$ and the concentration of carbonate ions in the water column, and increases the availability of bicarbonate ions (Kleypas et al., 1999). Several studies have found that coral calcification rates are directly related to the concentration of carbonate ions in the water column (Anthony et al., 2008; Gattuso 
et al., 1998; Kleypas et al., 2006; Marubini et al., 2008), whereas another study has shown a positive relationship between coral growth rates and the availability of bicarbonate ions (Jury et al., 2010). It has also been suggested that both the carbonate and bicarbonate ions affect coral calcification under acidified seawater conditions, but the extent of the effect differs in light and dark conditions (Comeau et al., 2013). Therefore, the response of coral growth and the state of the ocean's carbonate chemistry is under intensive investigation (Pandolfi et al., 2011).

The oceans are not homogeneous, and the temperature gradient from the tropics to the poles sets carbonate ion concentrations naturally higher in the tropics where coral reefs occur. Nevertheless, the decrease in carbonate ion concentrations from the pre-industrial period to the present has been greater in the tropics $\left(\sim 29 \mu \mathrm{mol} \mathrm{kg}^{-1}\right)$ than in the Southern Ocean $\left(\sim 18 \mu \mathrm{mol} \mathrm{kg}^{-1}\right)$ (Orr et al., 2005). Yet, symbiosis is prolific in the tropics, and the self-extending symbiosis theory tells us that organisms harboring symbionts should be more tolerant to environmental change than organisms without symbionts (i.e., aposymbiotic organisms) (Kitano, 2004; Kitano and Oda, 2006). These assertions lead to two pertinent questions: (i) Will calcifying coral species survive in high $p \mathrm{CO}_{2}$ seawater? (ii) Are juvenile corals, without symbionts, more vulnerable to high $p \mathrm{CO}_{2}$ seawater than juveniles and adult corals with symbionts?

Previous experiments that have mimicked the near-future $p \mathrm{CO}_{2}$ conditions on coral reefs have adjusted the $\mathrm{pH}$ of seawater either by adding an acid or a base, or by bubbling $\mathrm{CO}_{2}$ through the seawater in experimental chambers (Atkinson and Cuet, 2008). Adding an acid or a base results in seawater with different alkalinity, bicarbonate, and carbonate ion concentrations than when $\mathrm{CO}_{2}$ is bubbled through seawater (Atkinson and Cuet, 2008). Thus, adding an acid or a base has not been used in recent ocean acidification studies. Although bubbling $\mathrm{CO}_{2}$ through the seawater more closely reflects near-future conditions than adding acids, it is nevertheless difficult to achieve a stable $p \mathrm{CO}_{2}$ environment, especially in flow-through systems (e.g., Leclercq et al., 2002; Suwa et al. 2010; Takahashi and Kurihara, 2013). To overcome these problems, our research group developed a system that produced stable $p \mathrm{CO}_{2}$ concentrations in flow-through conditions (Fujita et al., 2011).

Using this system, we examined the effect of $p \mathrm{CO}_{2}$ adjusted seawater on the calcification rates of Acropora digitifera, one of the most common corals in the Pacific Ocean. Calcification was examined in five $p \mathrm{CO}_{2}$ treatments: (i) pre-industrial $p \mathrm{CO}_{2},<300 \mu \mathrm{atm}$, (ii) present-day $p \mathrm{CO}_{2}$ at $400 \mu \mathrm{atm}$, and at three near-future conditions of (iii) $600 \mu \mathrm{atm}$, (iv) $800 \mu \mathrm{atm}$, and (v) $1000 \mu \mathrm{atm}$. Within these treatments, we investigated the response of: (1) primary aposymbiotic coral polyps (i.e., without symbionts), (2) primary symbiotic polyps, and (3) adult symbiotic fragments. It was hypothesized that the calcification process of symbiotic corals was more tolerant to $p \mathrm{CO}_{2}$ adjustments than aposymbiotic corals.

\section{Materials and methods}

\subsection{Experimental setup}

To produce $p \mathrm{CO}_{2}$-adjusted seawater, we used a precise $p \mathrm{CO}_{2}$ control system (Fujita et al., 2011). This system was used to generate five different $p \mathrm{CO}_{2}$ levels, including one lower than the present level of atmospheric $p \mathrm{CO}_{2}$ : (i) preindustrial, $<300 \mu \mathrm{atm}$, (ii) present-day $p \mathrm{CO}_{2}$ at $400 \mu \mathrm{atm}$, and at three near-future conditions of (iii) $600 \mu \mathrm{atm}$, (iv) $800 \mu \mathrm{atm}$, and (v) $1000 \mu \mathrm{atm}$. The $p \mathrm{CO}_{2}$-adjusted seawater was supplied to duplicate flow-through $\left(150 \mathrm{~mL} \mathrm{~min}^{-1}\right)$ aquaria systems $(12 \mathrm{~L})$. The seawater temperature was maintained at $27^{\circ} \mathrm{C}$, with a $12: 12 \mathrm{~h}$ light: dark photoperiod (of $75 \mu \mathrm{mol} \mathrm{m}^{-2} \mathrm{~s}^{-1}$ ) under metal-halide lamps (Funnel2 150W, Kamihata, Japan) throughout all treatments. The aragonite saturation state of the seawater was estimated using the CO2SYS program (Lewis and Wallace, 1998) and the variables: temperature, $\mathrm{pH}$, mean salinity, and total alkalinity were measured repeatedly during the experiments. The chemical and physical conditions of each $p \mathrm{CO}_{2}$ treatment are summarized in Tables 1 and 2 .

\subsection{Primary polyp experiment}

Several $20 \mathrm{~cm}$ A. digitifera colonies were collected from a fringing reef of Sesoko Island, Okinawa, Japan. Gametes from two colonies, which spawned on 29 May 2010, were combined in a flow-through aquarium, from which we derived several hundred planulae larvae. Primary polyps were prepared following the methods outlined in our previous report (Suwa et al., 2010) using 13 day-old planulae. To prepare the symbiotic primary polyps, primary polyps of $A$. digitifera were infected with the dinoflagellate Symbiodinium (clade A, Tanaka et al., 2013). These dinoflagellates were derived from the giant clam Tridacna crocea (a solution of $4 \times 10^{5}$ cells $\mathrm{mL}^{-1}$ ) and were used because the primary polyps could acquire algae from this bivalve more efficiently than from other hosts, including Acropora species (Hirose et al., 2008). Four days after inducing metamorphosis, primary polyps were exposed to the symbiont solution for one day. Three days after exposure to the symbiont solution, we confirmed symbiont infection using a dissecting microscope. On the final day of the experiment, many symbionts (which were identical to the symbionts in Tanaka et al., 2013) were observed in infected polyps. The primary polyps, both with and without symbionts, were subjected to four $p \mathrm{CO}_{2}$ treatments: (i) pre-industrial, $<300 \mu \mathrm{atm}$, (ii) present-day $p \mathrm{CO}_{2}$ at $400 \mu \mathrm{atm}$, (iii) $800 \mu \mathrm{atm}$, and (iv) $1000 \mu \mathrm{atm}$.

Eight 6-well culture plates, containing the settled primary polyps, were placed into each of 8 aquariums (i.e., 4 plates for aposymbiotic primary polyps, and 4 plates for symbiotic 
primary polyps) for 10 days. A total of 20 polyps per treatment were used to evaluate skeletal growth of polyps. At the end of the experiment, soft tissues were removed from each polyp with a jet of high-pressure water from a dental-hygiene tool. The dry weight of each polyp skeleton was measured according to Inoue et al. (2011). The dry weight $(\mu \mathrm{g})$ of the polyp skeleton, at the end of the experiment, was used to represent the amount of growth of each coral during the experiment.

\subsection{Adult-coral-fragment experiment}

Five $>30 \mathrm{~cm}$ colonies of A. digitifera were collected in August 2009 from a shallow $(2 \mathrm{~m})$ fringing reef at Sesoko Island, Okinawa, Japan. The colonies, which were growing at least $10 \mathrm{~m}$ apart, were haphazardly selected. The A. digitifera colonies were kept in a flow-through aquarium for 3 weeks under natural light conditions at Sesoko Station, Tropical Biosphere Research Center, University of the Ryukyus (Okinawa, Japan). Fifty $2-3 \mathrm{~cm}$ fragments were cut from each parent colony and attached to plastic bolts with superglue. The fragments were kept in a flow-through aquarium for 2 weeks under natural light conditions until the coral tissues started to spread over the surfaces of the plastic bolts. Five of these fragments, from each parent colony, were maintained for 6 weeks in each of 10 aquaria, to which $p \mathrm{CO}_{2}$-adjusted seawater was supplied using the flow-through system (two aquaria per $p \mathrm{CO}_{2}$ treatment).

The weight of each colony was measured as buoyant weight (Davies, 1989), which directly reflects skeletal weight (Anthony et al., 2008). The calcification rate was calculated as the percentage change in final weight relative to the initial weight, during the 6-week experiment (see also Fig. S1). During the adult fragment experiment, 29 fragments died (11.6\% of 250 fragments) and were excluded from the calcification analysis. To evaluate the photosynthetic fitness of zooxanthellae in the adult fragments, the symbionts' maximum photosynthetic quantum yields $\left(F_{v} / F_{m}\right)$ were measured after 6 weeks using a Diving-PAM Underwater Fluorometer (Walz, Germany) after at least $1 \mathrm{~h}$ of darkness.

\subsection{Data analysis}

In the primary polyp experiment, the dry weights of the primary polyp skeleton were analyzed using a two-factor crossed analysis of variance (ANOVA), in which $p \mathrm{CO}_{2}$ (with four levels) and symbiosis (i.e., presence or absence of dinoflagellates) were incorporated into the model as fixedeffect factors. The subsequent pairwise comparisons among different $p \mathrm{CO}_{2}$ levels were performed using Tukey's HSD (honestly significant difference) tests $(\alpha=0.01)$.

In the adult-coral-fragment experiment, we used a generalized linear model to estimate the response of adultcoral calcification to $p \mathrm{CO}_{2}$ (fixed-effect factor), aquarium (nested within $p \mathrm{CO}_{2}$; fixed-effect factor), colony (fixed-

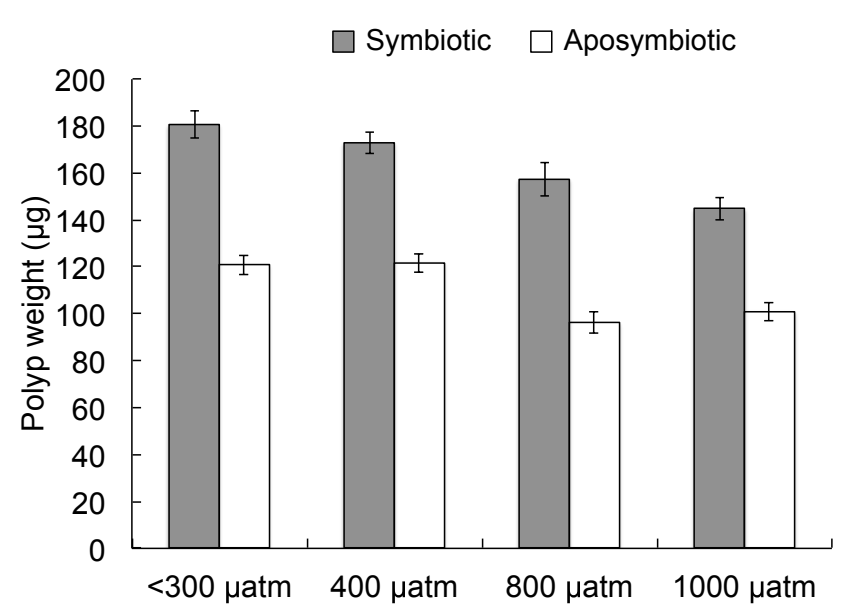

Fig. 1. Skeletal weights of primary polyps of Acropora digitifera in the (i) pre-industrial $p \mathrm{CO}_{2},<300 \mu \mathrm{atm}$, (ii) present-day $p \mathrm{CO}_{2}$ at $400 \mu \mathrm{atm}$, and at two near-future conditions of (iii) $800 \mu \mathrm{atm}$, and (iv) $1000 \mu \mathrm{atm}$. Bars show \pm S.E.

effect factor), initial weight (covariate), and their interactions $\left(p \mathrm{CO}_{2} \times\right.$ initial weight, colony $\times$ initial weight, colony $\times p \mathrm{CO}_{2}$, colony $\times p \mathrm{CO}_{2} \times$ initial weight). The result of the $F$ tests (based on type-III sum of squares) and stepwise backward model selection suggested that only $p \mathrm{CO}_{2} \times$ initial weight, and colony $\times$ initial weight remained as statistically significant interactions (each $\alpha=0.05$ ). To remove the variation of covariates, we calculated the adjusted mean final weights relative to the mean initial weight for each colony, assuming that their regression lines were heterogeneous among all the combinations of colony and $p \mathrm{CO}_{2}$. The adjusted final weight for each colony was independently analyzed using an ANOVA model with $p \mathrm{CO}_{2}$ (fixed-effect factor) and aquarium (nested within $p \mathrm{CO}_{2}$; fixed-effect factor) as the independent fixed factors. Statistically significant factors $(\alpha=0.01)$ were subjected to pairwise comparisons (Tukey's HSD tests; $\alpha=0.01$ ) to specify significant combinations of treatment levels. The $F v / F m$ values of adult fragments were analyzed using a one-way ANOVA model with $p \mathrm{CO}_{2}$ as fixed-effect factors after an arcsine transformation. The subsequent pairwise comparisons among different $p \mathrm{CO}_{2}$ levels were performed using Tukey's HSD tests $(\alpha=0.01)$.

\section{Results}

With regard to the primary polyp experiment, the ANOVA results indicated that the $p \mathrm{CO}_{2} \times$ symbiosis interaction was statistically negligible $(p>0.05)$, and the main factors were all significant $(p<0.0001)$. The post hoc tests demonstrated that the skeletal weights at $<300$ and $400 \mu \mathrm{atm}$ were significantly heavier than those at future-level treatments (i.e., 800 and $1000 \mu \mathrm{atm})$, regardless of whether polyps contain dinoflagellates or not (Fig. 1). When compared with the 
Table 1. Summary of mean physical and chemical conditions in each $p \mathrm{CO}_{2}$ treatment of the primary polyp experiment. Standard deviation is shown for $\mathrm{pH}_{T}$ and $p \mathrm{CO}_{2}$. The mean salinity and total alkalinity measured repeatedly during the experiments were 34.6 and $2257 \mathrm{~mol} \mathrm{~kg}-1$, respectively. The value of $\Omega$ arg was calculated using total alkalinity and $p \mathrm{CO}_{2}$. (i) pre-industrial $p \mathrm{CO}_{2},<300 \mu$ atm, (ii) present-day $p \mathrm{CO}_{2}$ at $400 \mu \mathrm{atm}$, and at two near-future conditions of (iii) $800 \mu \mathrm{atm}$, and (iv) $1000 \mu \mathrm{atm}$. All values are shown as mean \pm standard deviation.

\begin{tabular}{lcccc}
\hline Treatment & Temperature $\left({ }^{\circ} \mathrm{C}\right)$ & $\mathrm{pH}_{\mathrm{T}}$ at $25^{\circ} \mathrm{C}$ & $p \mathrm{CO}_{2}(\mu \mathrm{atm})$ & $\Omega \arg$ \\
\hline (i) Pre-industrial & 27.0 & $8.143 \pm 0.014$ & $279 \pm 13$ & 4.21 \\
(ii) Present & 27.1 & $8.040 \pm 0.015$ & $391 \pm 18$ & 3.47 \\
(iii) $600 \mu \mathrm{atm}$ & 27.1 & $7.896 \pm 0.033$ & $621 \pm 24$ & 2.56 \\
(iv) $800 \mu \mathrm{atm}$ & 27.1 & $7.793 \pm 0.022$ & $842 \pm 33$ & 2.05 \\
(v) $1000 \mu \mathrm{atm}$ & 27.1 & $7.719 \pm 0.029$ & $1048 \pm 44$ & 1.73 \\
\hline
\end{tabular}

same $p \mathrm{CO}_{2}$ level, the primary polyps with symbionts became heavier than those without dinoflagellates (Fig. 1). Because gametes from two colonies were added to each aquarium, genetic differences could not be incorporated into the model. However, it is unlikely that this changes our conclusion, because the error variance was small compared with the variance that was due to the main treatment effects in our data (see Table S1).

We evaluated the calcification rates of adult fragments of A. digitifera under five $p \mathrm{CO}_{2}$ treatments. The ANOVA on the adult fragment weight, adjusted for initial size variation, indicated that a higher $p \mathrm{CO}_{2}$ led to significantly slower growth rates in four out of the five colonies (Colony b-e; Fig. 2; Table S3). The results of the analysis also suggested that the potential environmental differences between two replicate aquaria were negligible in all five colonies (all $p>0.05$ ). The subsequent Tukey's HSD tests indicated that the mean final weight of adult fragments, reared at $<300 \mu \mathrm{atm}$, was significantly greater than those at the other $p \mathrm{CO}_{2}$ conditions in all of the four colonies, showing significant $p \mathrm{CO}_{2}$ effects (Fig. 2; Table S3). The maximum photosynthetic efficiencies of the adult fragments were above 0.6, and did not differ significantly among $p \mathrm{CO}_{2}$ treatments (Fig. 2; Table S4). These observed values indicated that there was negligible or no light-induced damage caused by the lighting system used in the experiment.

\section{Discussion}

The differences in the skeletal weights between primary polyps with and without symbionts might reflect the difficulty that aposymbiotic corals may have in acquiring energy and resources, including organic matrix molecules, for calcification. Yet why would the primary polyps with symbionts be more responsive to pre-industrial treatments than aposymbiotic primary polyps? The increase in calcification in the pre-industrial $p \mathrm{CO}_{2}$ treatment only occurred in corals that housed symbionts. Indeed, the adult colonies showed the same response as primary polyps with symbionts, clearly increasing calcification rates in low $p \mathrm{CO}_{2}$ treatments. Moreover, the calcification rates of symbiotic adult $A$. digitifera fragments were higher in the pre-industrial seawater $p \mathrm{CO}_{2}$ treatment than in the present-day $p \mathrm{CO}_{2}$ treatment.

Higher calcification in the pre-industrial $p \mathrm{CO}_{2}$ treatment was most likely attributed to a change in skeletal precipitation by the coral host, because there was no evidence of any dynamic photoinhibition (Enriquez et al., 2002) indicated as a decline in maximum photosynthetic quantum yield among the symbionts in the high- $p \mathrm{CO}_{2}$ treatments (Fig. 2, Table S4). Still, there were no differences in calcification rates between present-day and near-future concentrations (Fig. 2). We note that this lack of difference in calcification between present-day and anticipated future $p \mathrm{CO}_{2}$ treatments was not apparent for primary polyps (Fig. 1). These differences suggest a number of potential mechanisms that are not mutually exclusive. First, an increase in calcification in low $p \mathrm{CO}_{2}$ environments was only apparent in the presence of symbionts. Therefore, such phenotypic plasticity in calcification potential was most likely attributed to the presence of the symbionts. Second, the adult colonies did not respond to higher $p \mathrm{CO}_{2}$ environments, whereas the primary polyps with symbionts did show reduced calcification rates at high $p \mathrm{CO}_{2}$. Such results suggest a hierarchical response in tolerance to $p \mathrm{CO}_{2}$ environments, from adult colonies with symbionts as the most tolerant, to symbiotic primary polyps showing some tolerance, to primary polyps without symbionts being the least tolerant to high $p \mathrm{CO}_{2}$ treatments.

There is mounting evidence that symbiotic dinoflagellates facilitate calcification within corals through a positive feedback system between the host and the symbionts (Allemand et al., 2004; Muscatine, 1990; Yellowlees et al., 2008), although the detailed mechanisms have been under investigation. The glycerol and oxygen produced by the symbionts facilitate calcification through mitochondrial respiration and ATP (Adenosine triphosphate) production, which could be used for ion transport (Allemand et al., 2004; ColomboPallotta et al., 2010). $\mathrm{CO}_{2}$ uptake by photosynthesis is also thought to stimulate calcification by changing the equilibrium of dissolved inorganic carbon (DIC) in coral tissue, although the mechanisms are unresolved (Allemand et al., 2004). Our results also indicate that the primary polyps with symbionts grew faster than aposymbiotic polyps (Fig. 1). 


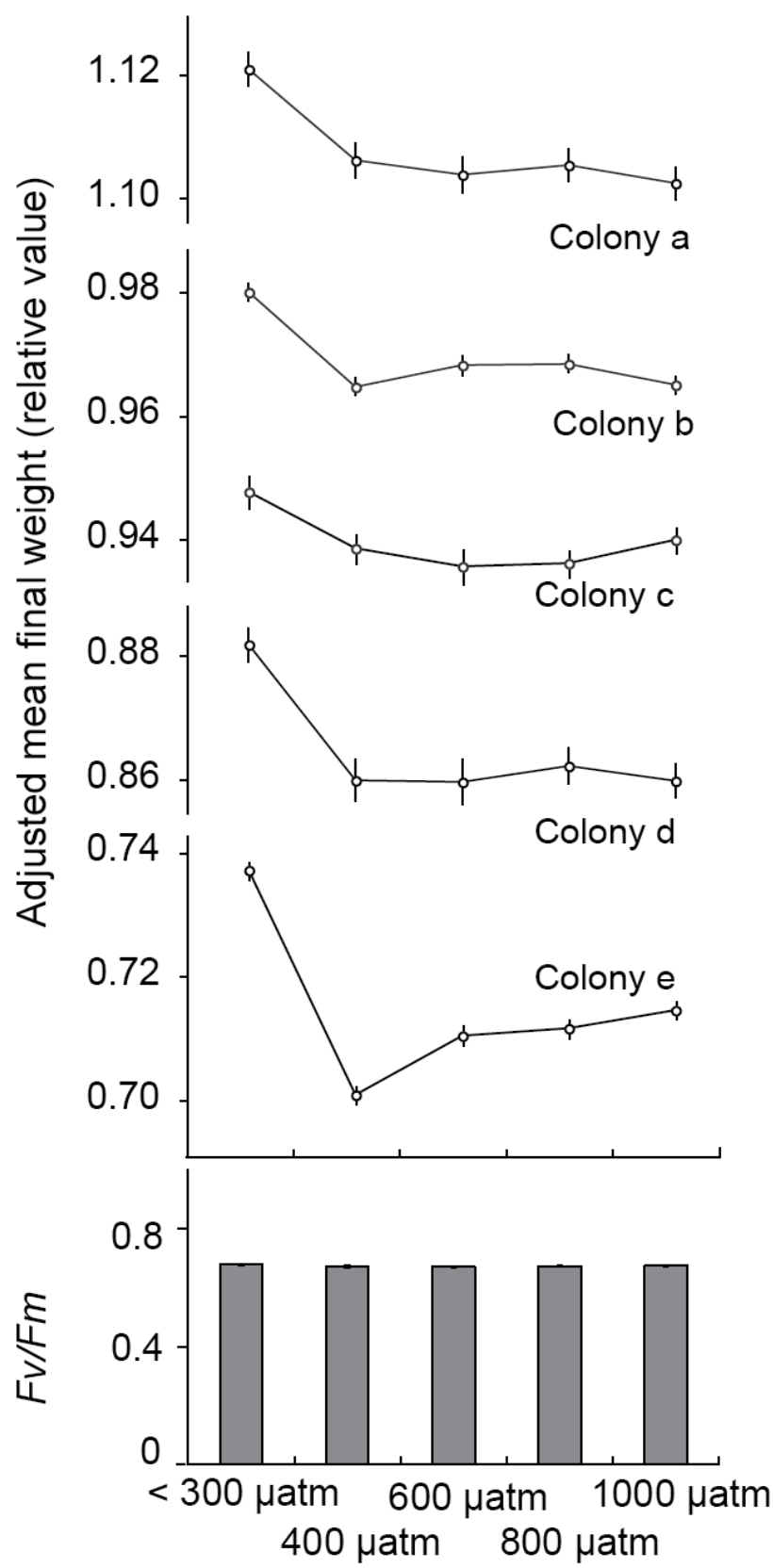

Fig. 2. Adjusted mean final weights of coral fragments and mean $\mathrm{Fv} / \mathrm{Fm}$ values from five colonies (Colonies a-e) of Acropora digitifera in the five $p \mathrm{CO}_{2}$ treatments: (i) pre-industrial $p \mathrm{CO}_{2}$, $<300 \mu \mathrm{atm}$, (ii) present-day $p \mathrm{CO}_{2}$ at $400 \mu \mathrm{atm}$, and at three nearfuture conditions, (iii) $600 \mu \mathrm{atm}$, (iv) $800 \mu \mathrm{atm}$, and (v) $1000 \mu \mathrm{atm}$. Bars show \pm S.E.

Although the primary polyps with symbionts seemed to be more sensitive to acidified seawater than aposymbiotic polyps (Fig. 1), the faster growth induced by symbiosis could compensate for the decrease of calcification by acidified seawater. The reason why coral/algal symbiosis enhances coral calcification is not only attributed to algal photosynthesis but is also potentially related to the removal of substances inhibiting calcification, such as phosphates (Allemand et al., 2004).

Previous research indicates that acidified seawater increases the concentration of $\mathrm{HCO}_{3}^{-}$, possibly followed by the activation of photosynthesis in coral symbionts (Jury et al., 2010; Marubini et al., 2008). In our experiments, however, there was no evidence that acidified seawater activates the photosynthesis of Acropora digitifera. The reason why the acidified seawater, with high $p \mathrm{CO}_{2}$ concentration $(1000 \mu \mathrm{atm})$, did not affect adult coral calcification and photosynthetic efficiency is unknown. We suspect that there were obvious advantages from symbiosis. For example, the removal of phosphates would facilitate calcification even in acidified seawater. Irrespective of the cellular mechanism involved, our results clearly showed that corals without symbionts were most vulnerable to $p \mathrm{CO}_{2}$ increases, whereas corals that housed symbionts were more tolerant.

These results suggest that coral recruitment might be influenced by ocean acidification. Given that globally $\sim 80 \%$ of the scleractinian corals are spawners that acquire symbionts from the "wild" after settlement (Baird et al., 2009), vulnerability of primary polyps to ocean acidification upon first settlement (in particular aposymbiotic polyps) could be at risk of decline in the near future. The same possibility was suggested by other recent studies (Albright et al., 2008; Cohen et al., 2009; Suwa et al., 2010; Albright and Langdon, 2011; Albright, 2011; de Putron et al., 2011; Dufault et al., 2012; Doropoulos et al., 2012; Dufault et al., 2013), although the comparative study between aposymbiotic and symbiotic primary polyps is only in its infancy (Inoue et al., 2012; Tanaka et al., 2013). This inference on recruitment may be particularly evident in the Indian and Pacific oceans, where most corals are spawners that horizontally transfer symbionts (Harrison and Wallace, 1990), acquiring them after settlement. By contrast, newly settled corals may do better in the Caribbean, where most corals are brooders and symbionts are maternally (i.e., vertically) acquired, and the planulae are symbiotic (Harrison and Wallace, 1990).

The degree of selective pressure by ocean acidification on newly settled polyps may therefore depend on how rapidly corals are able to support symbionts. Such selective filtering could lead to relative shifts in coral species abundance, changing reefs from those that primarily support spawners to reefs that primarily support brooders (that maternally acquire symbionts). Similar shifts in species composition have occurred in the Oligocene, when rapidly cooling oceans favored brooding corals over spawning corals in the Caribbean (Edinger and Risk, 1995).

In summary, the increase in $p \mathrm{CO}_{2}$ of just $100 \mu \mathrm{atm}$ between the pre-industrial period and the present had more effect on the calcification rate of adult A. digitifera than the anticipated future increases of several hundreds of microatmospheres of $p \mathrm{CO}_{2}$. Our results also suggest that ocean acidification has had adverse effects on reef corals since the 
industrial revolution. Ocean acidification, therefore, may not be only a future problem but a direct and present threat to ocean ecosystems (Talmage and Gobler, 2010). However, we also need to consider that the seawater $\mathrm{pH}$ and $p \mathrm{CO}_{2}$ in coral reefs can be variable over diel timescales (Suzuki et al., 1995; Ohde and van Woesik, 1999; Bates et al., 2001; Santos et al., 2011). Kitada et al. (2006) reported a relatively large $p \mathrm{CO}_{2}$ diurnal variation of 680-290 $\mu$ atm with seasonal variations in reef water in front of Sesoko Station. Thus, the natural $\mathrm{pH}$ and $p \mathrm{CO}_{2}$ variation in coral reefs should be taken into account to accurately predict the effect of ocean acidification. In conclusion, this study showed that the apparent sensitivity of primary polyps to near-future ocean acidification was a consequence of not housing symbionts, and those organisms harboring symbionts, at any life-history stage, are more tolerant to ocean acidification than organisms without symbionts.

\section{Supplementary material related to this article is available online at http://www.biogeosciences.net/10/ 6807/2013/bg-10-6807-2013-supplement.pdf.}

\begin{abstract}
Acknowledgements. This study was supported by the Global Environment Research Fund of the Ministry of the Environment of Japan, including the AICAL (Acidification Impact on CALcifiers) project (A-0804, A-1203) and RF-1009. We thank I. Koike, Y. Loya, A. Baird, N. Kumagai and Sandra van Woesik for valuable comments. T. Ono and H. Ushie provided total alkalinity data; C. Shinzato provided the dinoflagellate Symbiodinium.
\end{abstract}

Edited by: A. Shemesh

\section{References}

Albright, R., Mason, B., and Langdon, L.: Effect of aragonite saturation state on settlement and post-settlement growth of Porites astreoides larvae, Coral Reefs, 27, 485-490, doi:10.1007/s00338-008-0392-5, 2008.

Albright, R., Mason, B., Miller, M., and Langdon, C.: Ocean acidification compromises recruitment success of the threatened Caribbean coral Acropora palmata, Proc. Natl. Acad. Sci. USA, 107, 20400-20404, doi:10.1073/pnas.1007273107, 2010.

Albright, R., Langdon, C.: (2011) Ocean acidification impacts multiple early life history processes of the Caribbean coral Porites asteroids, Glob., Change Biol., 17, 2478-2487, doi:10.1111/j.1365-2486.2011.02404.x, 2011.

Albright, R.: Reviewing the Effects of Ocean Acidification on Sexual Reproduction and Early Life History Stages of Reef-Building Corals, J. Mar. Biol., 2011, 473615, doi:10.1155/2011/473615, 2011.

Allemand, D., Ferrier-Pagès, C., Furla, P., Houlbrèque, F., Puverel, S., Reynaud, S., Tambutté, É., Tambutté, S., and Zoccola, D.: Biomineralisation in reef-building corals: from molecular mechanisms to environmental control, CR Palevol., 3, 453-467, doi:10.1016/j.crpv.2004.07.011, 2004.

Anthony, K. R. N., Kline, D. I., Diaz-Pulido, G., Dove, S., and Hoegh-Guldberg, O.: Ocean acidification causes bleaching and productivity loss in coral reef builders, Proc. Natl. Acad. Sci. USA, 105, 17442-17446, doi:10.1073/pnas.0804478105, 2008.

Atkinson, M. J. and Cuet P.: Possible effects of ocean acidification on coral reef biogeochemistry: topics for research, Mar. Ecol. Prog. Ser., 373, 249-256, doi:10.3354/meps07867, 2008.

Baird, A. H., Guest, J. R., and Willis, B. L.: Systematic and biogeographical patterns in the reproductive biology of scleractinian corals, Ann. Rev. Ecol. Evol. Syst., 40, 551-571, doi:10.1146/annurev.ecolsys.110308.120220, 2009.

Bates, N. R., Samuels, L., and Merlivat, L.: Biogeochemical and physical factors influencing seawater $f \mathrm{CO}_{2}$ and air-sea $\mathrm{CO}_{2}$ exchange on the Bermuda coral reef, Limnol. Oceanogr., 46, 833846, doi:10.4319/lo.2001.46.4.0833, 2001.

Cohen, A. L., McCorkle, D. C., de Putron, S., Gaetani, G. A., and Rose, K. A.: Compositional and morphological changes in the skeletons of juvenile corals reared in acidified seawater: insights into the biomineralization response to ocean acidification, Geochem. Geophys. Geosyst., 10, Q07005, doi:10.1029/2009GC002411, 2009.

Colombo-Pallotta, M. F., Rodriguez-Román, A., and IglesiasPrieto, R.: Calcification in bleached and unbleached Montastraea faveolata: evaluating the role of oxygen and glycerol, Coral Reefs, 29, 899-907, doi:10.1007/s00338-010-0638-x, 2010.

Comeau, S., Carpenter, R. C., and Edmunds, P. J.: Coral reef calcifiers buffer their response to ocean acidification using both bicarbonate and carbonate, Proc. Biol. Sci., 280, 20122374. doi:10.1098/rspb.2012.2374, 2013.

de Putron, S. J., McCorkle, D. C., Cohen, A. L., and Dillon, A. B.: The impact of seawater saturation state and bicarbonate ion concentration on calcification by new recruits of two Atlantic corals, Coral Reefs, 30, 321-328, doi:10.1007/s00338010-0697-z, 2011.

Doropoulos, C., Ward, S., Diaz-Pulido, G., Hoegh-Guldberg, O., and Mumby, P. J.: Ocean acidification reduces coral recruitment by disrupting intimate larval-algal settlement interactions, Ecol. Lett., 15, 338-346, doi:10.1111/j.14610248.2012.01743.x, 2012.

Dufault, A. M., Cumbo, V. R., Fan, T. Y., and Edmunds, P. J.: Effects of diurnally oscillating $p \mathrm{CO}_{2}$ on the calcification and survival of coral recruits, Proc. Biol. Sci., 279, 2951-2958, doi:10.1098/rspb.2011.2545, 2012.

Dufault, A. M., Ninokawa, A., Bramanti, L., Cumbo, V. R., Fan, T. Y., and Edmunds, P. J.: The role of light in mediating the effects of ocean acidification on coral calcification, J. Exp. Biol., 216, 1570-1577, doi:10.1242/jeb.080549, 2013.

Edinger, E. N. and Risk M. J., Preferential survivorship of brooding corals in a regional extinction, Paleobiol., 21, 200-219, 1995.

Enriquez, S., Merino, M., and Iglesias-Prieto, R.: Variations in the photosynthetic performance along the leaves of the tropical seagrass Thalassia testudinum, Mar. Biol., 140, 891-900, doi:10.1007/s00227-001-0760-y, 2002.

Fujita, K., Hikami, M., Suzuki, A., Kuroyanagi, A., Sakai, K., Kawahata, H., and Nojiri, Y.: Effects of ocean acidification on calcification of symbiont-bearing reef foraminifers, Biogeosciences, 8, 2089-2098, doi:10.5194/bg-8-2089-2011, 2011. 
Gattuso, J. P., Frankignoulle, M., Bourgeb, I., Romaine, S., and Buddemeier, R. W.: Effect of calcium carbonate saturation of seawater on coral calcification, Global Planet., Change, 18, 3746, doi:10.1016/S0921-8181(98)00035-6, 1998.

Harrison, P. L. and Wallace, C. C.: Reproduction, dispersal and recruitment of scleractinian corals. In Coral Reefs, edited by: Dubinsky, Z., (Amsterdam, Elsevier), 133-207, 1990.

Hirose, M., Yamamoto, H., and Nonaka, M.: Metamorphosis and acquisition of symbiotic algae in planula larvae and primary polyps of Acropora spp., Coral Reefs, 27, 247-254, doi:10.1007/s00338-007-0330-y, 2008.

Hoegh-Guldberg, O., Mumby, P. J., Hooten, A. J., Steneck, R. S., Greenfield, P., Gomez, E., Harvell, C. D., Sale, P. F., Edwards, A. J., Caldeira, K., Knowlton, N., Eakin, C. M., Iglesias-Prieto, R., Muthiga, N., Bradbury, R. H., Dubi, A., and Hatziolos, M. E.: Coral reefs under rapid climate change and ocean acidification, Science, 318, 1737-1742, doi:10.1126/science.1152509, 2007.

Inoue, M., Suwa, R., Suzuki, A., Sakai, K., and Kawahata, H.: Effects of seawater $\mathrm{pH}$ on growth and skeletal U/Ca ratios of Acropora digitifera coral polyps, Geophys. Res. Lett., 38, L12809, doi:10.1029/2011GL047786, 2011.

Inoue, M., Shinmen, K., Kawahata, H., Nakamura, T., Tanaka, Y., Kato, A., Shinzato, C., Iguchi, A., Kan, H., Suzuki, A., Sakai, K.: Estimate of calcification responses to thermal and freshening stresses based on culture experiments with symbiotic and aposymbiotic primary polyps of a coral, Acropora digitifera, Glob. Planet. Change, 92-93, 1-7, doi:10.1016/j.gloplacha.2012.05.001, 2012.

IPCC: Climate Change 2007: The Physical Science Basis. Contribution of Working Group I to the Fourth Assessment Report of the Intergovernmental Panel on Climate Change, edited by: Solomon, S., Qin, D., Manning, M., Chen, Z., Marquis, M., Averyt, K. B., Tignor, M., and Miller, H. L., Cambridge University Press, Cambridge, UK and New York, NY, USA, 996 pp., 2007.

Jury, C. P., Whitehead, R. F., and Szmant, A. M.: Effects of variations in carbonate chemistry on the calcification rates of Madracis auretenra (= Madracis mirabilis sensu Wells, 1973): bicarbonate concentrations best predict calcification rates, Global Change Biol., 16, 1632-1644, doi:10.1111/j.13652486.2009.02057.x, 2010.

Kitada, Y., Fujimura, H., Tokeshi, R., and Oomori, T.: Air-sea $\mathrm{CO}_{2}$ flux and gas exchange coefficient at the Sesoko coral reefs, Okinawa, Japan. J. Japanese Coral Reef Soc., 8, 51-60, 2006.

Kitano, H.: Biological robustness, Nature Rev. Genet., 5, 826-837, doi:10.1038/nrg1471, 2004.

Kitano, H. and K. Oda, K., Self-extending symbiosis: a mechanism for increasing robustness through evolution, Biological Theory, 1, 61-66, doi:10.1162/biot.2006.1.1.61, 2006.

Kleypas, J. A., Buddemeier, R. W., Archer, D., Gattuso, J.-P., Langdon, C., Opdyke, B. N.: Geochemical consequences of increased atmospheric carbon dioxide on coral reefs, Science 284, 118120, doi:10.1126/science.284.5411.118, 1999.

Kleypas, J. A., Feely, R. A., Fabry, V. J., Langdon, C., Sabine, C. L., and Robbins, L. L.: Impacts of ocean acidification on coral reefs and other marine calcifiers: A guide for future research, report of a workshop held 18-20 April 2005, St. Petersburg, FL, sponsored by NSF, NOAA, and the US Geological Survey, 88 pp., 2006.

Leclercq, N., Gattuso, J. P., and Jaubert, J.: Primary production, respiration, and calcification of a coral reef mesocosm under in- creased $\mathrm{CO}_{2}$ partial pressure, Limnol. Oceanogr., 47, 558-564, doi:10.4319/lo.2002.47.2.0558, 2002.

Lewis, E. and Wallace, D. W. R., Program developed for $\mathrm{CO}_{2}$ system calculations, ORNL/ CDIAC-105. Carbon Dioxide Information Analysis Center, Oak Ridge National Laboratory, Oak Ridge, 1998.

Marubini, F., Christine, A. E., Ferrier-Page's, A. E., Furla, P., and Allemand, D.: Coral calcification responds to seawater acidification: a working hypothesis towards a physiological mechanism, Coral Reefs, 27, 491-499, doi:10.1007/s00338-008-03756, 2008.

Muscatine, L.: The role of symbiotic algae in carbon and energy flux in reef corals. In: Dubinsky Z (ed) Ecosystems of the world 25. Coral Reefs. Elsevier, Amsterdam, 75-87, 1990.

Ohde, S. and van Woesik, R.: Carbon dioxide flux and metabolic processes of a coral reef, Okinawa. Bull. Mar. Sci., 65, 559-576, 1999.

Orr, J. C., Fabry, V. J., Aumont, O., Bopp, L., Doney, S. C., Feely, R. A., Gnanadesikan, A., Gruber, N., Ishida, A., Joss, F., Key, R. M., Lindsay, K., Maier-Reimer, E., Matear, R., Monfray, P., Mouchet, A., Najjar, R. G., Plattner, G. K., Rodgers, K. B., Sabine, C. L., Sarmiento, J. L., Schlitzer, R., Slater, R. D., Totterdell, I. J., Weirig, M. F., Yamanaka, Y., and Yool, A.: Anthropogenic ocean acidification over the twenty first century and its impact on calcifying organisms, Nature, 437, 681-686, doi:10.1038/nature04095, 2005.

Pandolfi, J. M., Connolly, S. R., Marshall, D. J., and Cohen, A. L.: Projecting Coral Reef Futures Under Global Warming and Ocean Acidification, Science, 333, 418-422, doi:10.1126/science.1204794, 2011.

Raven, J., Caldeira, K., Elderfield, H., Hoegh-Guldberg, O., Liss, P., Riebesell, U., Shepherd, J., Turley, C., and Watson, A.: Ocean acidification due to increasing atmospheric carbon dioxide, Policy Document 12/05. Royal Society, London, 2005.

Santos, I. R., Glud, R. N., Maher, D., Erler, D., and Eyre, B. D.: Diel coral reef acidification driven by porewater advection in permeable carbonate sands (Heron Island, Great Barrier Reef), Geophy. Res. Lett., 38, L03604, doi:10.1029/2010GL046053, 2011.

Spencer, P. S.: Short-term growth measurements of corals using an accurate buoyant weighing technique, Mar. Biol., 101, 389-395, doi:10.1007/BF00428135, 1989.

Stanley, G. D. Jr, and Fautin, D. G.: The origins of modern corals, Science, 291, 1913-1914, doi:10.1126/science.1056632, 2001.

Suwa, R., Nakamura, M., Morita, M., Shimada, K., Iguchi, A., Sakai, K., and Suzuki, A.: Effects of acidified seawater on early life stages of scleractinian corals (Genus Acropora), Fish. Sci., 76, 93-99, doi:10.1007/s12562-009-0189-7, 2010.

Suzuki, A., Nakamori, T., and Kayanne, H.: 1995. The mechanism of production enhancement in coral reef carbonate systems: model and empirical results, Sediment. Geol., 99, 259-280, 1995.

Takahashi, A. and Kurihara, H.: Ocean acidification does not affect the physiology of the tropical coral Acropora digitifera during a 5-week experiment, Coral Reefs, 32, 305-314, doi:10.1007/s00338-012-0979-8, 2013.

Talmage, S. C. and Gobler, C. J.: Effects of past, present, and future ocean carbon dioxide concentrations on the growth and survival of larval shellfish, Proc. Natl. Acad. Sci. USA, 107, 1724617251, doi:10.1073/pnas.0913804107, 2010. 
Tanaka, Y., Iguchi, A., Inoue, M., Mori, C., Sakai, K., Suzuki, A., Kawahata, H., and Nakamura, T.: Microscopic observation of symbiotic and aposymbiotic juvenile corals in nutrient-enriched seawater. Mar. Poll. Bull., 68, 93-98, doi:10.1016/j.marpolbul.2012.12.017, 2013.
Yellowlees, D., Rees, T. A. V., and Leggat, W.: Metabolic interactions between algal symbionts and invertebrate hosts, Plant Cell Env., 31, 679-694, doi:10.1111/j.1365-3040.2008.01802.x, 2008. 